\title{
Article \\ Antimicrobial Activity of Selected Medicinal Plants from a Sub-Saharan African Country against Bacterial Pathogens from Post-Operative Wound Infections
}

\author{
Enid Owusu ${ }^{1, *}$, Martin Mensah Ahorlu ${ }^{1}$, Emmanuel Afutu ${ }^{2}$, Amos Akumwena ${ }^{2}$ and George Awuku Asare ${ }^{1}$ \\ 1 Department of Medical Laboratory Sciences, School of Biomedical and Allied Health Sciences, \\ University of Ghana, Accra 00233, Ghana; martunahorlu@gmail.com (M.M.A.); gaasare@ug.edu.gh (G.A.A.) \\ 2 Department of Medical Microbiology, School of Biomedical and Allied Health Sciences, \\ College of Health Sciences, University of Ghana, Accra 00233, Ghana; emmalineafutu@yahoo.com (E.A.); \\ aakumwena@yahoo.com (A.A.) \\ * Correspondence: enidowusu115@yahoo.com; Tel.: +233-0508-917-569
}

check for updates

Citation: Owusu, E.; Ahorlu, M.M.; Afutu, E.; Akumwena, A.; Asare, G.A. Antimicrobial Activity of Selected Medicinal Plants from a Sub-Saharan African Country against Bacterial Pathogens from Post-Operative Wound Infections. Med. Sci. 2021, 9 , 23. https://doi.org/10.3390/ medsci9020023

Academic Editor: Giuliana Banche

Received: 14 February 2021

Accepted: 25 March 2021

Published: 31 March 2021

Publisher's Note: MDPI stays neutral with regard to jurisdictional claims in published maps and institutional affiliations.

Copyright: (C) 2021 by the authors Licensee MDPI, Basel, Switzerland. This article is an open access article distributed under the terms and conditions of the Creative Commons Attribution (CC BY) license (https:// creativecommons.org/licenses/by/ $4.0 /)$.

\begin{abstract}
Background: Globally, the application of medicinal plants in the management of acute and chronic wounds can be considered a common occurrence in most traditional medicine practices. In view of this, many plants in the tropical and subtropical regions have been screened for their woundhealing activities. Consequently, plants having antimicrobial activity against multidrug-resistant (MDR) pathogens can be considered great assets. Therefore, this study evaluated ethanolic and aqueous extracts of five medicinal plants (Psidium guajava, Myrianthus arboreus, Alchornea cordifolia, Momordica charantia, and Justicia flava) for their antimicrobial activities against MD-R bacterial pathogens isolated from post-operative wounds; Methods: This involved the aqueous and ethanolic extraction of the selected medicinal plants. Preliminary phytochemical constituents of the plants were examined. The agar well diffusion method was then used to determine the antibacterial activity of the leaves against reference strains (Escherichia coli ATCC 25922, Salmonella typhi ATCC 19430, Pseudomonas aeruginosa ATCC 27853 and Staphylococcus aureus ATCC 25923, and a Methicillin-Resistant Staphylococcus aureus strain) as well as the MDR clinical isolates (E. coli, P. aeruginosa, S. aureus and CoNS) from the wounds; Results: The preliminary phytochemical analysis of the leaves showed the presence of saponins, phenolics, and reducing sugars in almost all the plants tested. All plant extracts were observed to have some antimicrobial activity against at least one reference strain. For the clinical MDR isolates, $A$. cordifolia from this study showed highest inhibition to growth of all bacteria used. Activity of J. flava against $S$. aureus was highest as compared to that of E.coli and P. aeruginosa. Similar observation was made for $M$. arboreus, $P$. guajava and $M$. charantia where the highest activity was observed against S. aureus; Conclusion: This study has mainly shown that P. guajava, M. arboreus, A. cordifolia, M. charantia, and J. flava exhibits antimicrobial activities against MD-R bacterial pathogens isolated from post-operative wounds. Also, these plants has bioactive phytochemical compounds with potential medicinal values for the treatment of numerous infections. Therefore, these plants may be helpful in the management of acute and chronic wounds, especially in traditional medicine practices.
\end{abstract}

Keywords: bacteria; herbal; plants; MDR; resistance; susceptibility; wound

\section{Introduction}

Since their discovery, antibiotics have been indispensable in the treatment of microbial infections (especially bacterial infections) and have helped in extending the average life expectancy [1]. Globally, antibiotics have had significant useful impact, including the reduction of morbidity and mortality rate caused by bacterial infections in humans, particularly in the developing countries with limited public health infrastructure [2]. Antibiotics have however been overused and misused in the general population, resulting in an increase in antibiotic resistance rates among several microorganisms $[1,2]$. 
Hence in recent years, antibiotic resistance has been recognized as a major global health threat $[2,3]$. Consequently, efforts have been made to counteract the antibiotic resistance menace, while exploring alternative sources of antimicrobial agents, such as medicinal plants [3].

Psidium guajava L. (Myrtaceae), Myrianthus arboreus P. Beauv. (Cecropiaceae), Alchornea cordifolia (Schumach. \& Thonn.) Müll.Arg. (Euphorbiaceae), Momordica charantia L. (Cucurbitaceae) and Justicia flava (Forssk.) Vahl. (Acanthaceae) are among the tropical plants used for the treatment of various ailments [4-14].

Myrianthus arboreus P. Beauv. is a dioecious shrub or tree and belongs to the family Cecropiaceae. It is found growing in forest zones of tropical Africa, including Ghana. Extracts of the leaves and leafy shoots of Myrianthus arboreus are used in the treatment of dysentery, wounds, diarrhea, boils, dysmenorrhea and incipient hernia [7]. The oil from the leaves is mainly made up of linoleic acids, which maintains the skin's impermeability to water [7]. This plant has been observed to exhibit activities against some pathogens including Plasmodia spp., Mycobacteria spp. and Trypanosoma spp. [7].

Alchornea cordifolia (Schumach. \& Thonn.) Müll.Arg. of the family Euphorbiaceae is an evergreen dioecious shrub and grows in some Sub-Saharan African countries including Senegal, Kenya, Tanzania, DR Congo and Ghana [4]. The leaves are normally used as infusions for the treatment and management of some respiratory and intestinal problems whiles the poultice of the leaves is used for the treatment of wounds [4]. The leaves and root bark of $A$. cordifolia are externally applied to treat leprosy and as antidote to snake venom [4]. The leaves, roots and stem bark have been found to contain terpenoids, steroid glycosides, flavonoids, tannins, saponins, carbohydrate, alkaloids, and several guanidine alkaloids [4]. Different extracts of the leaf, stem bark and root of $A$. cordifolia have been shown to have significant antibacterial and antifungal activity. The ethanolic extracts of the leaves and fruits have shown significant antimicrobial activity on a number of pathogens including Trypanosoma spp., helminthes and some bacteria [4].

Momordica charantia L. (Cucurbitaceae) is used in the Amazon, parts of Asia and Africa for its numerous benefits in the treatment of skin infections. The fruits and leaves have been observed to contain saponin-like substances and phenolic compounds [5]. The plant has also been shown to contain anti-tumor properties [6]. A leaf tea of this plant has been used for diabetes, to treat menstrual problems, and as anti-viral agent against hepatitis and measles viruses.

Justicia flava (Forssk.) Vahl. of the family Acanthaceae is found growing in various locations including disturbed habitat, in full sun or semi shady areas and on a wide range of soil types. It is very common in tropical and southern Africa [14] and used in traditional medicine for the treatment of diarrhea and dysentery, cough, fever, epilepsy, skin infections and disorders, among others [7,8]. According to Agyare et al. [9], in recent times, there seems to be no report on pharmacological activity for J. flava, despite its popular use in traditional (herbal) medicine. Regarding its constituents, steroids including campesterol, stigmasterol, sitosterol and sitosterol-D-glucoside have been detected in the leaves and roots of J. flava $[10,11]$.

Psidium guajava L. (Myrtaceae) is an important medicinal plant in the tropics [13]. The bark is used in the treatment of diarrhea, stomach ache and diabetes whiles extract of the leaves has been described to be used for the treatment of bronchitis, asthma attacks and for the treatment of dysentery [12]. It constituents include tannins from the bark, monoterpenoids and esters from the ripe fruit, essential oil from the leaves, as well as terpenoids from leaves and in the outer portion [14]. Clinical isolates found to show susceptibility towards P. guajava include wound isolates of Proteus spp., Staphylococcus spp. and Pseudomonas aeruginosa [14].

These plants are widely available in Ghana and are believed to possess wound healing abilities by the indigenous people of the study location. In addition to these reasons, their documented properties $[4,6-8,12-14]$ made them suitable candidates for the current study. 
Globally, the application of medicinal plants in the management of acute and chronic wounds can be considered a common occurrence in most traditional medicine practices. In view of this, many plants in the tropical and subtropical regions of the world have been screened for their wound-healing abilities $[7,14,15]$. Despite the growing menace of antibiotic resistance, and the fact that plants are a promising source of antibiotics with possible activity on multidrug-resistant microorganisms [3], the potential of plant extracts as alternative sources of novel antibiotics against wound pathogens have been under-explored, especially in developing countries. Thus, there still exists a number of medicinal plants to be screened in the search for newer, efficacious, and cost effective wound-healing properties.

For example, in Nigeria, Udegbunam and colleagues investigated the wound healing and antibacterial properties of Pupalia lappacea Juss [16], Crinum jagus [17] and Stephania dinklagei [17]. In Ghana, Boakye et al. [18] determined the in vivo wound-healing activity of aqueous aerial part extract of a medicinal plant using the case of only Phyllanthus muellerianus. Also, Agyare and colleagues [14] evaluated the antimicrobial and wound healing potential of two plants; Justicia flava and Lannea welwitschii.

It is therefore important to explore more plants that are locally widely available and of low cost, as potential sources of novel antibiotics (specifically against wound infected bacterial pathogens) to contribute to effective management of wound infections. To help achieve this goal, the current study evaluated ethanolic and aqueous extracts of five medicinal (Psidium guajava (P. guajava), Myrianthus arboreus (M. arboreus), Alchornea cordifolia (A. cordifolia), Momordica charantia (M. charantia) and Justicia flava (J. flava)) for their antimicrobial activities against multidrug-resistant (MD-R) bacterial pathogens isolated from post-operative wounds.

\section{Materials and Methods}

\subsection{Study Design, Location and Ethical Considerations}

A quantitative experimental research was carried out at the Microbiology Departments, Central Laboratory, Korle Bu Teaching Hospital (KBTH), and the School of Biomedical and Allied Health Sciences (SBAHS) all of the Greater Accra Region of Ghana, as well as the Centre for Plant Medicine Research (CPMR), Mampong of the Ashanti Region of Ghana. In addition to the Microbiology Department of the SBAHS, the Korle-Bu Teaching Hospital, one of the leading national referral center in Ghana and the third largest hospital in Africa, aided in the clinical isolation of the selected bacteria. The CPMR which focuses on research into herbal medicines has an ultramodern extraction laboratory as well as a microbiology laboratory which helped in the preparation and the microbiological analysis of the plant extracts.

The study was conducted in accordance with existing ethical guidelines after receiving ethical clearance from the Ethical and Protocol Review Committee of the College of Health Sciences, University of Ghana with protocol identification number: CHS-Et/M.5P5.13/2018-2019.

\subsection{Herbal Preparations}

\subsubsection{Macroscopic Examination and Preparation of Extracts}

The medicinal plants used were Alchornea cordifolia (Schumach. \& Thonn.) Müll.Arg. (Euphorbiaceae), Myrianthus arboreus P. Beauv. (Cecropiaceae), Psidium guajava L. (Myrtaceae), Momordica charantia L. (Cucurbitaceae) and Justicia flava (Forssk.) Vahl. (Acanthaceae). Identification of these plants was ascertained at the Botany Department of the University of Ghana. One kilogram each of the plant leaves was examined macroscopically for any the presence foreign matter (contaminants such as molds, insects and undesirable material) after which they were washed with distilled water and air dried at room temperature $\left(28-32{ }^{\circ} \mathrm{C}\right)$ for 14 days in a shed at the Centre for Plant Medicine Research. The completely dried plant leaves were then pulverized with a pulverizer mill into coarse powder. The herbs used for this study were prepared as herbal extracts and decoctions. 
Methods used included extraction techniques, maceration and decoction as described by Sukhdev et al. [19].

\subsubsection{Ethanolic Extraction}

The extraction of the plant material followed the method as performed and documented by Sukhdev et al. [19]. Briefly, two hundred grams (200 g) of pulverized dried leaves (coarse powder) of the plants were weighed out using an analytical weighing scale.

Three and half liters of $70 \% v / v$ ethanol was added to it and left to macerate for 4 days at room temperature $\left(28-32{ }^{\circ} \mathrm{C}\right)$, with occasional stirring. After the 4 days, the $70 \%$ ethanol was decanted and filtered through a Whatman No. 1 filter paper (Sigma-Aldrich Inc., St. Louis, MO, USA). The extracts were then concentrated in an oven with relatively lower heat at $38^{\circ} \mathrm{C}$ for $24 \mathrm{~h}$ and stored in a refrigerator at $4{ }^{\circ} \mathrm{C}$.

\subsubsection{Aqueous Extraction}

Two hundred grams each of the dried leaves of the plants (coarse powder) were brought to boil in $3.5 \mathrm{~L}$ of distilled water on a hot plate for about one hour thirty minutes and then strained. The aqueous extracts were filtered using Whatman No. 1 filter paper (Sigma-Aldrich Inc., St. Louis, MO, USA), and subsequently cooled for $45 \mathrm{~min}$. After cooling, the extracts were concentrated using the drying oven with relatively lower heat at $38^{\circ} \mathrm{C}$ for $24 \mathrm{~h}$ and stored in a refrigerator at $4{ }^{\circ} \mathrm{C}$.

\subsubsection{Preliminary Phytochemical Investigations}

Preliminary phytochemical analysis using standard procedures described by Evans [20] was used to determine the phytochemical constituents present in the plants. Saponins, phenolics, reducing sugar, flavonoids, polyuronides, cardiac glycosides, anthracenosides, triterpenes, phytosterol and alkaloids were determined. Briefly, for reducing sugars, $1 \mathrm{~mL}$ of extracts was diluted with water $(2 \mathrm{~mL})$ in a test tube. Fehling's solutions I $(1 \mathrm{~mL})$ and Fehling's solution II $(1 \mathrm{~mL})$ were added and heated in a water bath at $90{ }^{\circ} \mathrm{C}$, forming a brick-red precipitate.

For saponins, diluted solution of the extracts $(2 \mathrm{~mL})$ was placed in a test tube and shaken for $15 \mathrm{~min}$. A soapy like column of about $2 \mathrm{~cm}$ formed above liquid level. For alkaloids, the extracts $(15 \mathrm{~mL})$ were evaporated to dryness in an oven at $55^{\circ} \mathrm{C}$ and residue dissolved in 10\% v/v Hydrochloric acid $(10 \mathrm{~mL})$. Ten milliliters $(10 \mathrm{~mL})$ of $10 \% v / v$ ammonia solution was added to precipitate the alkaloids and then extracted with ether $(15 \mathrm{~mL})$. The ether portion was evaporated to dryness and $1.5 \mathrm{~mL}$ of hydrochloric acid added. To $0.5 \mathrm{~mL}$ of the acidic solution was added 2-3 drops of Mayer's reagents forming opalescence precipitate.

To detect cardiac glycosides, anthracenosides and flavonosides, $25 \mathrm{~mL}$ of the extracts was mixed in $10 \% v / v$ hydrochloric acid $(15 \mathrm{~mL})$, refluxed for $30 \mathrm{~min}$, cooled and extracted with diethyl ether $(36 \mathrm{~mL})$ in portions of $12 \mathrm{~mL}$ each. For cardiac glycosides, to a residue obtained by evaporating to dryness extracts $(10 \mathrm{~mL})$ was added acetic anhydride $(0.50 \mathrm{~mL})$ and chloroform $(0.50 \mathrm{~mL})$ and transferred into a dry tube. Concentrated Sulphuric acid $(2 \mathrm{~mL})$ was added by means of a pipette at the bottom of the tube forming reddish-brown ring at the contact zone of the two layers. For anthracenosides, the extract $(4 \mathrm{~mL})$ was added to concentrated Sulphuric acid $(2 \mathrm{~mL})$ and shaken with $25 \% v / v$ ammonia solution $(2 \mathrm{~mL})$ forming cherished-red solution on the top layer. For, flavonosides the residue obtained by evaporating the extracts $(5 \mathrm{~mL})$ was heated in $50 \%$ methanol $(2 \mathrm{~mL})$. Metallic magnesium $(0.5 \mathrm{~g})$ and concentrated Hydrochloric acid ( 5 drops) was added forming a red solution. 


\subsection{Bacteriological Analyses}

\subsubsection{Identification of Bacteria Isolates}

The bacterial isolates were obtained from archived wound swabs from the Microbiology Department of the School of Biomedical and Allied Health Sciences, University of Ghana, Korle-Bu, Accra. Bacterial isolate authentication was done by secondary culture of the archived isolates.

The collected isolates were thawed and cultured on blood and chocolate agar plates. Differential media of cystine-lactose-electrolyte-deficient agar (CLED) (Oxoid Ltd., Basingstoke, UK), deoxycholate citrate agar (DCA) (Neogen Co. Ltd. Lansing, MI, USA), and MacConkey agar (Sigma-Aldrich Inc., St. Louis, MO, USA) aided in distinguishing between Gram negative bacteria that are lactose fermenters (LF) and non-lactose fermenters (NLF). The isolates were ascertained based on colonial morphology, Gram staining and a battery of biochemical reactions, as defined by Ryan and Ray [21].

Characterization of the bacterial isolates was done phenotypically based on colonial morphology, Gram staining and biochemical tests. Below are detailed description of the isolates' characterization:

Escherichia coli: These isolates were characterized based on their presentation as Gramnegative rods in singles, indole-positive, motility-positive and lactose fermentation.

Pseudomonas aeruginosa: Characterization was based on their presentation as Gram-negative rods in singles, oxidase-positive and Pyocyanin (green pigment) production.

Staphylococcus aureus: These isolates were characterized based on their presentation as Gram-positive cocci in clusters, catalase-positive and coagulase positive.

Coagulase-negative staphylococci (CoNS): Characterization was based on their presentation as Gram-positive Cocci in clusters, catalase-positive and coagulase negative.

\subsubsection{Antibiotic Susceptibility Testing of Bacterial Isolates}

Identified bacterial colonies were purified and their susceptibility patterns were determined for various antibiotics using a modified form of the Kirby Bauer method [22,23]. Antibiotics tested included ampicillin, tetracycline, trimethroprim/sulfamethoxazole, gentamycin, cefuroxime, cefotaxime, amikacin, ciprofloxacin, levofloxacin, ceftazidime, meropenem, piperacillin/tazobactam, amoxicillin/clavulanic acid, cefepime, colistin, erythromycin, cefoxitin, vancomycin, teicoplanin and clindamycin. These antibiotics were tested because they seem to be common on the Ghanaian market.

The antibiotic susceptibility testing procedure employed is briefly described as follows. The test organism was emulsified in peptone water until the turbidity was comparable with $0.5 \%$ McFarland's standard. A loopful of the suspension was transferred onto a MuellerHinton agar plate (Sigma-Aldrich Inc., St. Louis, MO, USA), and then a sterile cotton swab was used to streak the entire surface of the plate. Sterile forceps were used to apply the antibiotic discs to the surface of the agar plate and incubated at $37^{\circ} \mathrm{C}$ for $18-24 \mathrm{~h}$. Zone diameters around the antibiotic discs were measured and classified as sensitive or resistant based on the Clinical and Laboratory Standards Institute (CLSI) break point system [24]. Isolates that were resistant to 3 or more antibiotics were labeled as multidrug resistant (MDR) and selected for testing with the plant extracts. Analysis were done in duplicates.

\subsubsection{Antimicrobial Activity Evaluation of Plant Extracts by Agar Well Diffusion Method}

The agar well diffusion method (CLSI) was used to screen for antibacterial activity of the leaves with reference strains (Escherichia coli ATCC 25922, Salmonella typhi ATCC 19430, Pseudomonas aeruginosa ATCC 27853 and Staphylococcus aureus ATCC 25923, and a Methicillin-Resistant Staphylococcus aureus strain) as well as the MDR clinical isolates from the wounds (E. coli, P. aeruginosa, S. aureus and CoNS). About three to four isolated colonies of similar morphology were picked from the 18-24 h agar plate of pure cultures using a sterile loop, and then inoculated individually into $4 \mathrm{~mL}$ peptone broth (Sigma, P0556, Sigma-Aldrich Inc., St. Louis, MO, USA). The density/turbidity of the inoculum 
was adjusted to 0.5 McFarland turbidity standard, resulting in a suspension of $1.5 \times 10^{8}$ CFU colony forming units.

Mueller Hinton agar plates (Oxoid, CM0337, Oxoid Ltd., Basingstoke, UK) were seeded with the test organisms and the plates left to dry for five minutes. After drying, wells were made in the agar using sterile cork borer measuring $9 \mathrm{~mm}$ in diameter. Hundred microliters $(100 \mu \mathrm{L})$ of the aqueous and ethanolic extract of leaves were dispensed into the labelled wells. The plates were then kept in the refrigerator for one hour for the extract to diffuse into the medium. The plates were then incubated at $37^{\circ} \mathrm{C}$ for $24 \mathrm{~h}(\mathrm{~h})$ and the zones of inhibition were measured in millimeters. Analysis were done in duplicates.

\subsection{Statistical Analysis}

The data collected in the study were entered into MS Excel and analyzed using Minitab software version 15 (Minitab Inc., State College, PA, USA). Descriptive analysis was carried out on the various plant extracts. For the antibiotic susceptibility testing of bacterial isolates, zone diameters around the antibiotic discs were measured and classified as sensitive or resistant based on the CLSI break point system [24]. Isolates that were resistant to 3 or more antibiotics were labeled as multidrug resistant isolates and the proportions of such isolates were also recorded. For the antimicrobial activity evaluation of the plant extracts using agar well diffusion method, the zone diameters around the wells were measured in millimeters and recorded.

\section{Results}

\subsection{Preliminary Phytochemical Constituents of the Plants}

The preliminary phytochemical analysis of the leaves of the five plants showed the presence of saponins, phenolics, and reducing sugars in all the plants with the exception of ethanolic extract of $J$. flava which did not have saponins and the ethanolic extract of $M$. charantia which did not have saponins and phenolics (Table 1). The presence of phytochemical compounds such as flavonoids, polyuronides, cardiac glycosides, anthracenosides, triterpens, phytosterol and alkaloids were not detected in the leaves of most of the plants used in this study in both aqueous and ethanolic extracts (Table 1).

Table 1. Phytochemical constituents of the aqueous and ethanolic extracts.

\begin{tabular}{|c|c|c|c|c|c|c|c|c|c|c|}
\hline \multirow{2}{*}{$\begin{array}{l}\text { Phytochemicals/ } \\
\text { Compounds }\end{array}$} & \multicolumn{2}{|c|}{ P. guajava } & \multicolumn{2}{|c|}{ M. charantia } & \multicolumn{2}{|c|}{ A. cordifolia } & \multicolumn{2}{|c|}{ M. arboreus } & \multicolumn{2}{|c|}{ J. flava } \\
\hline & Aq. & Eth. & Aq. & Eth. & Aq. & Eth. & Aq. & Eth. & Aq. & Eth. \\
\hline Saponins & + & + & + & - & + & + & + & - & + & - \\
\hline Phenolics & + & + & + & - & + & + & + & + & + & + \\
\hline Reducing sugar & + & + & + & + & + & + & + & + & + & + \\
\hline Flavonoids & - & + & - & - & + & - & - & - & - & - \\
\hline Polyuronides & + & - & - & - & - & - & - & - & - & - \\
\hline Cardiac Glycosides & - & - & - & - & - & - & - & - & - & - \\
\hline Anthracenosides & - & + & - & - & + & - & - & - & - & - \\
\hline Triterpenes & - & - & - & - & - & - & - & - & - & - \\
\hline Phytosterol & + & + & - & - & + & - & - & + & - & + \\
\hline Alkaloids & - & - & - & - & - & - & - & - & - & - \\
\hline
\end{tabular}

P. guajava: Psidium guajava, M. charantia: Momordica charantia, A. cordifolia: Alchornea cordifolia, M. arboreus: Myrianthus arboreus, J. flava: Justicia flava; Aq. represents aqueous extracts, Eth. represents ethanolic extracts; + indicates detection of phytochemical agents; - indicate non-detection or absence of phytochemical agents.

\subsection{Proportions of Clinical Isolates and Antimicrobial Susceptibility Patterns}

A total of 57 bacterial isolates from post-operative wounds were screened. The clinical isolates were in the following proportions; E. coli $(42.1 \%, 24 / 57)$, P. aeruginosa $(33.3 \%$, $19 / 57)$, S. aureus $(21 \%, 12 / 57)$ and CoNS $(3.5 \%, 2 / 57)$. Among these, all the E. coli and CoNS isolates (24 and 2, respectively) were found to be multidrug resistant (i.e., they were 
resistant to 3 or more antibiotics) whiles the other isolates displayed varying degree of multidrug resistance (Table 2).

Table 2. Proportions of multiple drug resistance among the different clinical isolates.

\begin{tabular}{cccc}
\hline \multirow{2}{*}{ Isolate } & Total Number & \multicolumn{2}{c}{ Number of Multiple Drug Resistant Isolates (MDR) (\%) } \\
\cline { 3 - 4 } & & MDR (\%) & Non-MDR (\%) \\
\hline E. coli & 24 & $24(100)$ & $0(0)$ \\
P. aeruginosa & 19 & $12(63)$ & $7(37)$ \\
S. aureus & 12 & $11(92)$ & $1(8)$ \\
CoNS & 2 & $2(100)$ & $0(0)$ \\
\hline
\end{tabular}

CoNS = Coagulase Negative Staphylococci.

With regards to the antimicrobial susceptibility patterns, for Gram negative clinical isolates tested in this study, E. coli isolates showed the highest resistance of 79\% (19/24) against cefepime but was highly susceptible to trimethoprim/sulfamethoxazole (100\% susceptibility) and meropenem (88\% susceptibility). Also E. coli isolates recorded resistance of $75 \%$ and $71 \%$ against amikacin and piperacillin/tazobactam respectively. The resistance recorded for $P$. aeruginosa clinical isolates ranged from $21 \%(4 / 19)$ to $84 \%(16 / 19)$ among the antibiotics tested. The highest resistance of $84 \%$ was recorded among three antibiotics, namely; ciprofloxacin, cefepime and colistin (Table 3).

For the Gram positive isolates, S. aureus, showed highest susceptibility to standard antibiotics such as ampicillin (92\% susceptibility) and vancomycin (75\% susceptibility), but highly resistant to amoxicillin/clavulanic acid with 83\% (10/12). For the coagulasenegative Staphylococci isolates tested in this study, high susceptibility (100\%) was observed for all standard antibiotics used, except for clindamycin and cefepime which recorded resistance of $100 \%$, apiece (Table 3). Antibiotic susceptibility pattern of individual isolates is presented in Supplementary File, Tables S1-S4.

\subsection{Antimicrobial Activity of Aqueous and Ethanolic Extracts against Reference Strains of Bacteria}

Regarding the antimicrobial activity of aqueous and ethanolic extracts against reference strains of bacteria, all plant extracts were observed to have some antimicrobial activity against at least one reference strain (Table 4). For A. cordifolia, relatively high antimicrobial activity was observed for aqueous extracts with zone of inhibition ranging from 19 to $29 \mathrm{~mm}$ and ethanolic extracts with zone of inhibition ranging from 17 to $28 \mathrm{~mm}$. For J. flava and $M$. arboreus mean zone of inhibition was zero for both E. coli ATCC 25922 and S. typhi ATCC 33458 with both aqueous and ethanolic extracts. However, J. flava showed a relatively moderate activity against MRSA (zone of inhibition; aqueous $=15 \mathrm{~mm}$, ethanol $=13 \mathrm{~mm}$ ) and S. aureus ATCC 25923 (zone of inhibition; aqueous $=18 \mathrm{~mm}$, ethanol =16 mm). Similarly, $M$. arboreus showed a relatively moderate activity against MRSA (zone of inhibition; aqueous $=15 \mathrm{~mm}$, ethanol = $12 \mathrm{~mm}$ ) and $S$. aureus ATCC 25923 (zone of inhibition; aqueous $=0 \mathrm{~mm}$, ethanol $=12 \mathrm{~mm}$ ).

For M. charantia, apart from E. coli ATCC 25922 which did not record any activity, zone of inhibition ranged from $10 \mathrm{~mm}$ to $18 \mathrm{~mm}$ for aqueous extracts and $10 \mathrm{~mm}$ to $26 \mathrm{~mm}$ for ethanolic extracts against the other isolates (Table 4). Both aqueous and ethanolic extracts of P. guajava also did not have activity also against E. coli ATCC 25922 but showed activity against the rest of the isolates with zone of inhibition ranging from $7 \mathrm{~mm}$ to $21 \mathrm{~mm}$ for ethanolic extracts and $8 \mathrm{~mm}$ to $26 \mathrm{~mm}$ for aqueous extracts. For P. guajava no activity was observed with aqueous extracts against S. typhi ATCC 33458 (Table 4). 
Table 3. Antimicrobial susceptibility pattern of Gram-negative and Gram-positive clinical isolates.

\begin{tabular}{|c|c|c|c|c|c|c|c|c|c|c|c|c|c|c|c|c|c|}
\hline \multirow{2}{*}{$\begin{array}{c}\text { Bacterial Isolates } \\
\text { Gram Negative }\end{array}$} & \multirow[b]{2}{*}{$\mathrm{N}$} & \multirow[b]{2}{*}{$\mathrm{S}, \mathrm{R}$} & \multicolumn{15}{|c|}{ Antimicrobial Agents/Number of Isolates (\%) } \\
\hline & & & AMP & TET & SXT & GEN & CXM & CTX & AMK & $\mathrm{CIP}$ & LEV & CAZ & MEM & TZP & AMC & FEP & CL \\
\hline \multirow[b]{2}{*}{ E. coli } & \multirow[b]{2}{*}{24} & $\mathrm{~S}$ & $22(92)$ & $23(96)$ & $24(100)$ & $1563)$ & $2188)$ & $22(92)$ & $6(25)$ & $21(88)$ & $22(92)$ & $20(83)$ & $21(88)$ & $7(29)$ & 19 (79) & $5(21)$ & - \\
\hline & & $\mathrm{R}$ & $2(8)$ & $1(4)$ & $0(0)$ & $9(37)$ & $3(12)$ & $2(8)$ & 18 (75) & $3(12)$ & $2(8)$ & $4(17)$ & $3(12)$ & $17(71)$ & $5(21)$ & $19(79)$ & - \\
\hline \multirow{2}{*}{ P. aeruginosa } & \multirow{2}{*}{19} & S & - & & (1) & $7(37)$ & - & 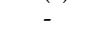 & $5(26)$ & $13(16)$ & $12(63)$ & $4(21)$ & $15(79)$ & $5(26)$ & - & $3(16)$ & $3(16)$ \\
\hline & & $\mathrm{R}$ & - & - & - & $12(63)$ & - & - & $14(74)$ & $16(84)$ & $7(37)$ & $15(79)$ & $4(21)$ & $14(74)$ & - & $16(84)$ & $16(84)$ \\
\hline Gram positive & & & AMP & TET & SXT & GEN & CXM & LEV & TZP & AMC & FEP & ERY & VA & FOX & $\mathrm{CC}$ & TEC & CL \\
\hline \multirow{2}{*}{ S. aureus } & \multirow{2}{*}{12} & $\mathrm{~S}$ & 11 (92) & $10(83)$ & $6(50)$ & $4(33)$ & $4(33)$ & $7(58)$ & $4(33)$ & $2(17)$ & $3(25)$ & - & $9(75)$ & - & $4(33)$ & $5(42)$ & - \\
\hline & & $\mathrm{R}$ & $1(8)$ & $2(17)$ & $6(50)$ & $8(67)$ & $8(67)$ & $5(42)$ & $8(67)$ & $10(83)$ & $9(75)$ & - & $3(25)$ & - & $8(67)$ & $7(58)$ & - \\
\hline CoNS & 2 & $\mathrm{~S}$ & $2(100)$ & $2(100)$ & $2(100)$ & $2(100)$ & $2(100)$ & $2(100)$ & $2(100)$ & $2(100)$ & $0(0)$ & $2(100)$ & $2(100)$ & $1(50)$ & $0(0)$ & $2(100)$ & $2(100)$ \\
\hline
\end{tabular}

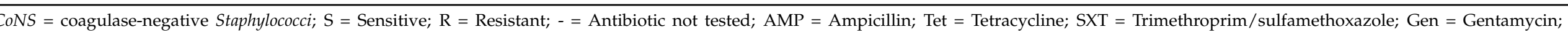

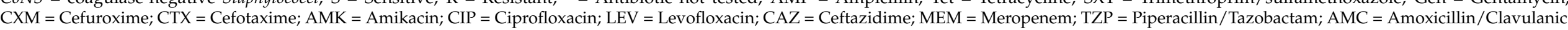
acid; FEP = Cefepime; $\mathrm{CL}=$ Colistin; ERY = Erythromycin, FOX = Cefoxitin, VA = Lancomycin, TEC = Teicoplanin and CC = Clindamycin 
Table 4. Antimicrobial activity of aqueous and ethanol plant extracts against the reference strains.

\begin{tabular}{|c|c|c|c|c|c|c|c|c|c|c|}
\hline \multirow{3}{*}{ Bacterial Control Strains } & \multirow{2}{*}{\multicolumn{2}{|c|}{$\begin{array}{c}\text { A. cordifolia } \\
\text { ZoI }(\mathrm{mm})\end{array}$}} & \multirow{2}{*}{\multicolumn{2}{|c|}{$\frac{\text { J. flava }}{\text { ZoI (mm) }}$}} & \multirow{2}{*}{\multicolumn{2}{|c|}{$\begin{array}{c}\text { M. arboreus } \\
\text { ZoI (mm) }\end{array}$}} & \multirow{2}{*}{\multicolumn{2}{|c|}{$\frac{\text { M. charantia }}{\text { ZoI }(\mathrm{mm})}$}} & \multirow{2}{*}{\multicolumn{2}{|c|}{$\begin{array}{c}\text { P. guajava } \\
\text { ZoI (mm) }\end{array}$}} \\
\hline & & & & & & & & & & \\
\hline & Aqueous & Ethanol & Aqueous & Ethanol & Aqueous & Ethanol & Aqueous & Ethanol & Aqueous & Ethanol \\
\hline P. aeruginosa ATCC 27853 & 19 & 17 & 0 & 0 & 0 & 0 & 15 & 10 & 8 & 20 \\
\hline E. coli ATCC 25922 & 29 & 28 & 0 & 0 & 0 & 0 & 0 & 0 & 0 & 0 \\
\hline S. typhi ATCC 33458 & 23 & 20 & 0 & 0 & 0 & 0 & 10 & 12 & 0 & 7 \\
\hline MRSA & 21 & 24 & 15 & 13 & 15 & 12 & 18 & 26 & 22 & 21 \\
\hline S. aureus ATCC 25923 & 28 & 27 & 18 & 16 & 0 & 12 & 18 & 13 & 26 & 21 \\
\hline
\end{tabular}

ZoI (mm) represents mean zones of inhibition measured in millimeters (mm); P. guajava: Psidium guajava, M. charantia: Momordica charantia, A. cordifolia: Alchornea cordifolia, M. arboreus: Myrianthus arboreus, J. flava: Justicia flava; MRSA: Methicillin-resistant Staphylococcus aureus.

\subsection{Antimicrobial Activity of Aqueous and Ethanolic Extracts against Clinical Isolates of Bacteria}

Table 5 presents results on mean zones of inhibition recorded for the aqueous and ethanolic plant extracts against the clinical bacteria isolates (See Supplementary File Tables S5-S7 for zones of inhibition of individual isolates). For the clinical MDR isolates, A. cordifolia from this study showed highest inhibition to growth of all bacteria, with the highest activity observed against $S$. aureus (mean zone of inhibition $21.4 \mathrm{~mm}=$ for aqueous extract and $23.4 \mathrm{~mm}$ for ethanolic extracts) (Table 5). Activity of J. flava against $S$. aureus was highest (6.4 $\mathrm{mm}$ for aqueous and $1.6 \mathrm{~mm}$ for ethanol) as compared to that of E. coli and $P$. aeruginosa. Similar observation was made for the other plants where high activity was observed against $S$. aureus; $M$. arboreus $(1.3 \mathrm{~mm}$ for aqueous and $0.6 \mathrm{~mm}$ for ethanol) and $M$. charantia $(9.9 \mathrm{~mm}$ for aqueous and $11.1 \mathrm{~mm}$ for ethanol). Also, P. guajava showed highest activity (16.1 $\mathrm{mm}$ for aqueous and $17.6 \mathrm{~mm}$ for ethanol) against $S$. aureus, followed by $P$. aeruginosa with zone of inhibition of $2.4 \mathrm{~mm}$ for aqueous and $9.2 \mathrm{~mm}$ for ethanolic extract (Table 5).

Table 5. Antimicrobial activity of aqueous and ethanol plant extracts against the clinical isolates.

\begin{tabular}{|c|c|c|c|c|c|c|c|c|c|c|c|c|}
\hline \multirow{2}{*}{ Isolate } & \multirow{2}{*}{$\mathbf{N}$} & & \multicolumn{2}{|c|}{ A. cordifolia } & \multicolumn{2}{|c|}{ J. flava } & \multicolumn{2}{|c|}{ M. arboreus } & \multicolumn{2}{|c|}{ M. charantia } & \multicolumn{2}{|c|}{ P. guajava } \\
\hline & & & Aqueous & Ethanol & Aqueous & Ethanol & Aqueous & Ethanol & Aqueous & Ethanol & Aqueous & Ethanol \\
\hline \multirow{3}{*}{ E. coli } & \multirow{3}{*}{25} & Mean ZoI (mm) & 9.2 & 23.0 & 0.7 & 0.0 & 0.0 & 0.4 & 0.3 & 1.0 & 0.0 & 0.3 \\
\hline & & STD & 7.1 & 3.1 & 2.6 & 0.0 & 0.0 & 2.2 & 1.6 & 2.9 & 0.0 & 1.6 \\
\hline & & SEM & 1.4 & 0.6 & 0.5 & 0.0 & 0.0 & 0.4 & 0.3 & 0.6 & 0.0 & 0.3 \\
\hline \multirow{3}{*}{ P. aeruginosa } & \multirow{3}{*}{20} & Mean ZoI (mm) & 14.2 & 16.1 & 0.4 & 0.0 & 0.6 & 0.0 & 4.14 & 4.4 & 2.4 & 9.2 \\
\hline & & STD & 5.3 & 4.8 & 1.6 & 0.0 & 1.9 & 0.0 & 6.0 & 5.9 & 4.5 & 6.9 \\
\hline & & SEM & 1.2 & 1.1 & 0.4 & 0.0 & 0.4 & 0.0 & 1.3 & 1.3 & 1.0 & 1.5 \\
\hline \multirow{3}{*}{ S. aureus } & \multirow{3}{*}{16} & Mean ZoI (mm) & 21.4 & 23.4 & 6.4 & 1.6 & 1.3 & 0.6 & 9.9 & 11.1 & 16.1 & 17.6 \\
\hline & & STD & 7.0 & 1.6 & 7.3 & 4.4 & 3.4 & 2.3 & 4.6 & 4.6 & 3.4 & 1.8 \\
\hline & & SEM & 1.7 & 0.4 & 1.8 & 1.0 & 0.8 & 0.6 & 1.1 & 1.1 & 0.9 & 0.4 \\
\hline
\end{tabular}

$\mathrm{N}$ represents total number, STD = standard deviation; SEM = standard error of mean; ZoI (mm) represents mean zones of inhibition measured in millimeters (mm); P. guajava: Psidium guajava, M. charantia: Momordica charantia, A. cordifolia: Alchornea cordifolia, M. arboreus: Myrianthus arboreus, J. flava: Justicia flava.

\section{Discussion}

Like many countries in Sub-Saharan Africa, Ghana hosts a number of plants with medicinal properties [25]. However, just a handful of studies have exploited the activity of these plants against wound infected bacterial pathogens $[14,18]$. For instance, Boakye et al. [18] determined the in vivo wound-healing activity of aqueous aerial part extract of a medicinal plant using the case of only Phyllanthus muellerianus. Agyare et al. [14] also evaluated the antimicrobial and wound healing potential of two plants; Justicia flava and Lannea welwitschii. However, most of these studies did not include a wide variety of plants and also did not target MDR wound isolates. Also, to the best of our knowledge, there seem to be limited attention given to post-operative wounds in this regard. To help fill this gap, the current study mainly evaluated ethanolic and aqueous extracts of five medicinal plants (Psidium guajava, Myrianthus arboreus, Alchornea cordifolia, Momordica 
charantia, and Justicia flava) for their antimicrobial activities against multidrug-resistant (MD-R) bacterial pathogens isolated from post-operative wounds. These low cost and easily accessible plants in Ghana have been suspected by natives to have wound healing properties, however, not all of these plants have been investigated. The current study therefore provides evidence supporting the antimicrobial activity of extracts of these plants against clinical bacterial isolates from wounds; alongside the preliminary phytochemical constituents of these plants.

The preliminary phytochemical screening of the aqueous and ethanolic extracts of the leaves of Psidium guajava, Myrianthus arboreus, Alchornea cordifolia, Momordica charantia, and Justicia flava in this study showed that the predominant compounds present in the plants were saponins, phenolics and reducing sugars. This observation is similar to several studies with regards to the phytochemical constituents of these plants [14,26-29]. In terms of health benefit, both saponins and phenolic compounds existing in plants have demonstrated potential medicinal values for the treatment of numerous diseases such as cancers, heartrelated illnesses, tumor, bacterial infections, and diabetes $[6,30,31]$. Therefore, this may account for why these plants have been useful to most people in Ghana (especially those at the countryside) regarding their wound problems; thereby leading to the suspicion of having would healing ability.

Compounds such as flavonoids, anthracenosides and phytosterol were found in some of the plants. Flavonoids are well known for their beneficial effects on health and according to Panche et al. [32], efforts are being made to isolate this ingredient. Flavonoids are considered as an essential component in a variety of pharmaceutical, nutraceutical, medicinal and cosmetic usage [32]. This compound have been found to have anti-oxidative, anti-inflammatory, anti-mutagenic and anti-carcinogenic properties in addition to their ability to modulate key cellular enzyme function [32].

However, other phytochemical compounds, such as alkaloids, triterpenes, and cardiac glycosides were not detected in both aqueous and ethanolic extracts of plants used in this study.

Akbari et al. [31] indicated that the recoveries of bioactive phytochemical compounds from plants are potentially affected by the conditions of extraction methods and different solvent formulations. Other investigators also asserted that the concentration of these compounds, which may or may not be detected in a phytochemical analysis, depends on the nature of the chemical used as solvent in the extraction process, as well the growth and storage conditions [33,34]. Based on all these reasons which may affect the detection of these compounds in the plants, it is therefore not surprising that some of these compounds were not detected. However, the absence of phenolics in M. charantia leaves observed in the current study can be considered an interesting finding, since it is against previous knowledge; warranting further investigation. Meanwhile, the current study did not employ HPLC fingerprinting or HPTLC screening for the phytochemical analyses; a limitation that can be considered in future investigations, since these techniques may provide more comprehensive phytochemical investigation.

The antimicrobial investigations from this study showed E. coli clinical isolates to have the highest resistance to cefepime, followed by amikacin and piperacillin/tazobactam, but was highly susceptible to trimethoprim/sulfamethoxazole and meropenem. This observation is in contrast to what was recently observed in Ethiopia by Tekele et al. [35] where E. coli (from various clinical specimens such as urine, pus, body fluids, sputum, stool, ear and eye discharges) showed the highest resistance to ampicillin followed by amoxicillin with clavulanic acid. Also, although E. coli isolates from this study showed the highest resistance to cefepime, followed by amikacin, a study by Yilmaz et al. [36] showed to $E$. coli (from urinary tract infections) as having the highest resistance to ampicillin. In that study [36] cefepime and amikacin recorded the 6th and 10th resistant antibiotics out of the 15 antibiotics they tested. However, similar to this study, Yilmaz et al. [36] observed high susceptibility to meropenem. 
P. aureginosa from this study was resistant to most antibiotics tested, with highest among them being ciprofloxacin, cefepime and colistin with $84 \%$ resistance. Similarly, Yayan et al. [37] have reported an elevated resistance of P. aeruginosa and MDR P. aeruginosa for cefepime in Germany. In a study by Siddiqua et al. [38] using P. aeruginosa from clinical specimens (wound, pus and urine), the isolated pathogens showed resistance to cefepime, ceftriaxone, cefotaxime and gentamicin from $47 \%$ to $88 \%$. All the isolates from their study were comparatively better susceptible to meropenem, similar to what is observed in this study with $79 \%$ susceptibility. However, ciprofloxacin which showed high resistance in this study also showed better susceptibility in their study. Studies in Ethiopia and India have noted $P$. aureginosa to be highly resistant to many antibiotics $[39,40]$. Therefore, judicious and rational treatment prescription by physicians to limit further the spread of antimicrobial resistance among the P. aeruginosa, as recommended by Siddiqua et al. [38] is highly supported by this study.

Staphylococcus aureus isolates showed highest susceptibility to standard antibiotics such as ampicillin ( $92 \%$ susceptibility) and vancomycin (75\% susceptibility), but highly resistant to amoxicillin/clavulanic acid with $83 \%(10 / 12)$. This pattern is similar to observations in Ethiopia where S. aureus was 100\% sensitive to vancomycin [40]. Deyno et al. [41] also observed S. aureus to show $75 \%$ resistance to ampicillin, however vancomycin recorded $11 \%$ resistance compared to $75 \%$ resistance recorded in this study. Deyno et al. [41] concluded that $S$. aureus in Ethiopia has gotten notoriously resistant to almost to all of antimicrobial agents in use, including, penicillin, cephalosporins, tetracyclines, chloramphenicol, methicillin, vancomycin and sulphonamides. In the current study, the resistance level observed for amoxicillin/clavulanic acid is bothersome and requires due attention. Meanwhile, studies conducted in Ethiopia and Nepal found S. aureus to be susceptible to aminoglycosides, such as amikacin [42-44].

For the Coagulase-Negative Staphylococci (CoNS) isolates tested in this study, high sensitivity rate was observed against almost all antibiotics used; however, for clindamycin and cefepime, there was $100 \%$ resistance. After testing CoNS strains isolated from a university teaching hospital in China (similar to the site of the current study-Korle-Bu Teaching Hospital) for antibiotic resistance, Ma et al. [45] observed clindamycin to be among antibiotics having resistance rate between 30 and $70 \%$. In that study, antibiotics were placed into three categories based on resistance levels of the CoNS strains to these antibiotics: high resistance (resistance rate $>70 \%$ ), including penicillin $\mathrm{G}$, oxacillin and erythromycin; medium resistance (resistance rate between 30 and 70\%), including tetracycline, clindamycin, ciprofloxacin, trimethoprim/sulfamethoxazole and chloramphenicol; and low resistance (resistance rate $<30 \%$ ), including rifampicin, ceftizoxime and gentamicin [45]. Also, high resistance rates of CoNS have been observed in southern Ethiopia for amoxicillin, amoxicillin-clavunilic acid, ampicillin, and tetracycline as $88.9 \%, 77.8 \%$, $77.8 \%$ and $77.8 \%$ respectively [42]. Therefore, the finding of high susceptibility rate against almost all antibiotics used in this study can be considered a positive one since one of the characteristics of CoNS is their resistance to multiple antimicrobial agents commonly used for the treatment of staphylococcal infections. Also, the high resistance rates of CoNS observed in other studies $[42,45]$ and the fact that CoNS have become increasingly recognized as important agents of nosocomial infection [45] puts the finding of high susceptibility observed in this study in a promising light.

Generally, possible reasons for these differences in resistance levels observed for all the isolates in this study as compared to other studies can be due to the methods employed for antimicrobial testing, variations in the pattern of indiscriminate usage of antibiotics, patients conditions (isolates from this study were solely from post-operative wound infections) and the nature of bacteria in these countries. Also, some of these drugs (like meropenem) have been on the Ghanaian market for a relatively short period of time compared to others whiles some are also very expensive and usually prescribed for serious infections compared to others. Thus, accounting for the relatively low levels of resistance observed in this study. 
Additionally, some of the resistance displayed by the bacterial isolates could be due to biofilm formation. Biofilms provides protection to the bacteria, giving additional resistance power which makes them to not only tolerate harsh conditions but also resistant to antibiotics, which may lead to multi drug resistant, extensively drug resistant and totally drug resistant bacteria [46]. Biofilm-related infections (which included wound infections) are notoriously hard to eradicate and have been a subject of intense scientific research [47]. Consequently, biofilms can have a significant impact on wound healing.

Therefore, biofilms may be considered contributory factors in some of the multi drug resistance observed in this study, although the study did not directly examine the contribution of biofilms.

Another notable limitation of this study is the fact that during the antibiotic susceptibility testing of bacterial isolates, the experiments were done only in duplicates instead of triplicates.

For the antimicrobial activity of aqueous and ethanolic extracts against the clinical isolates, Alchornea cordifolia from this study showed highest inhibition to growth of all bacteria used; the highest activity was observed against $S$. aureus for both aqueous and ethanolic extracts whiles E. coli was affected more by ethanolic extracts. Similarly, Igbenegu et al. [48] also reported that $A$. cordifolia was active against multi-resistant $S$. aureus. Ebi [49] investigated the antimicrobial properties of methanol extracts of $A$. cordifolia and observed that some fractions of the extracts, notably those containing phenolics and terpenoids, exhibited significant activity against $P$. aeruginosa, B. subtilis and E. coli. It is worth noting that, in this study, A. cordifolia also contained phenolics in both aqueous and ethanolic extracts. However, the isolates used in the current study are MDR and from post-operative wounds unlike that of Ebi [49] which could not be ascertained. Therefore, this plant may be very useful among individuals who may prefer traditional (herbal) medicine in the treatment of their post-operative wounds infected with MDR pathogens, such as those investigated in the current study.

A study by Adeyemi et al. [50] on activity of three different plants (including $A$. cordifolia) on isolates different from those studied in the current investigations showed all their three plant extracts to exhibit varying degrees of activity with $A$. cordifolia being the most active. According to Adeyemi et al. [50] the antibacterial properties of $A$. cordifolia has been extensively studied. Earlier Okeke et al. [51] had shown that it was very active against seventy four bacterial strains studied in vitro. Ajali [52] also made similar observations and the current finding is in line with these earlier reports; however adding that $A$. cordifolia may be useful in management of post-operative wounds. Also, considering the abundance of A. cordifolia in most parts of Ghana, this plant would be of benefit to many people in the study location.

Similar observation was made for the other plants where more activity was observed against S. aureus for M. arboreus, M. charantia, P. guajava and J. flava. According to Agyare et al. [53] extracts of Myrianthus arboreus and Alchornea cordifolia show some level of antimicrobial activity against common pathogens that cause infections in wounds (especially S. aureus and P. aureginosa). For M. charantia, similarly, Mwambete et al. [54] has shown antimicrobial activity against Pseudomonas aeruginosa, Escherichia coli, and Staphylococcus aureus. These pathogens (Staphylococcus sp. and Pseudomonas sp.) which are known to be among those commonly associated with wounds infections are also common in Ghana [53]. Therefore, finding various plants to have activity against these pathogens in the current study presents individuals who may prefer traditional medicine in the treatment of their post-operative wounds infected with MDR pathogens with a number of options; thus, readily using which of them is closely available to them.

The antimicrobial activity of the extracts could be attributed to the presence of flavonoids and other secondary metabolites. According to Agyare et al. [53] terpenoids are known to play a role in the antimicrobial activity of some plants due to the possible effect on the nonmevalonate pathway; a pathway that is very essential in most microorganisms (including Gram-negative bacteria) for the synthesis of cell membrane components and 
as a secondary source of carbon [53]. Therefore, as indicated earlier, future investigations using HPLC fingerprinting or HPTLC screening for all major phytochemicals and finding correlations between such secondary metabolites and the antimicrobial activity is in the right direction.

For J. flava Agyare et al. [14] demonstrated that methanol leaf extract was active against Escherichia coli ATCC 25922, Pseudomonas aeruginosa ATCC 4853 and Staphylococcus aureus ATCC 25923. However there seem to be limited studies showing its efficacy against clinical strains, especially those of MDR isolates from post-operative wound infection. Generally, there seems to be just few studies on the medicinal properties of J. flava although commonly available in Ghana [14].

In this study, P. guajava showing activity against $P$. aeruginosa confirms the observation by Abdelrahim et al. [55], who indicated that, in their study, all clinical isolates tested including that of $P$. aeruginosa were sensitive to extracts of $P$. guajava [55]. This observation confirms the traditional uses of this plant [56], which is also available in most parts of the study location (Ghana). According to Lins et al. [56], P. guajava has numerous properties including antioxidant, anti-allergic, anti-inflammatory and antimicrobial. This is likely the reason for which this plant and others investigated in the current study are widely used in traditional medicine for wound healing [4].

\section{Conclusions}

This study has mainly provided evidence to show that Psidium guajava, Myrianthus arboreus, Alchornea cordifolia, Momordica charantia, and Justicia flava exhibits antimicrobial activities against multidrug-resistant (MD-R) bacterial pathogens isolated from post-operative wounds. It has also showed that these plants have bioactive phytochemical compounds with potential medicinal values for the treatment of numerous infections.

Given the findings of this study, it is recommended that other plants which are being used by people in the treatment of wound infection be scientifically screened against MDR isolates. Also, since topical application of antimicrobials is an efficient therapeutic method of destroying microbial population because of the availability of the drug at the wound sites, further studies aimed at development of the plants investigated in the current study into topical forms for use in management of post-operative wounds is recommended.

Supplementary Materials: The following are available online at https: / www.mdpi.com/article / 10.3390/medsci9020023/s1, Table S1: Antibiotic Susceptibility pattern for Pseudomonas aeroginosa isolates, Table S2: Antibiotic Susceptibility pattern for Escherichia coli isolates, Table S3: Antibiotic Susceptibility pattern for Staphylococcus aureus isolates, Table S4: Antibiotic Susceptibility pattern for Coagulase-negative Staphylococci isolates, Table S5: Zones of inhibition ( $\mathrm{mm}$ ) recorded for aqueous and ethanol plant extracts against Pseudomonas aeruginosa, Table S6: Zones of inhibition $(\mathrm{mm})$ recorded for aqueous and ethanol plant extracts against Escherichia coli, Table S7: Zones of inhibition (mm) recorded for aqueous and ethanol plant extracts against Staphylococcus aureus.

Author Contributions: Conceptualization, E.O. and G.A.A.; Data curation, E.O., M.M.A. and A.A.; Formal analysis, E.O., M.M.A., E.A. and A.A.; Investigation, E.O., M.M.A., A.A. and G.A.A.; Methodology, E.O., M.M.A., E.A., A.A. and G.A.A.; Project administration, E.O. and G.A.A.; Resources, E.O., A.A. and G.A.A.; Software, M.M.A. and E.A.; Supervision, E.O. and G.A.A.; Validation, E.O., M.M.A., E.A., A.A. and G.A.A.; Visualization, E.O., M.M.A. and A.A.; Writing-original draft, E.O., M.M.A., E.A. and G.A.A.; Writing—review \& editing, E.O., M.M.A., E.A., A.A. and G.A.A. All authors have read and agreed to the published version of the manuscript.

Funding: This research received no external funding.

Institutional Review Board Statement: The study was conducted according to the guidelines of the Declaration of Helsinki and approved by the Ethical and Protocol Review Committee of the College of Health Sciences, University of Ghana with protocol identification number: CHS-Et/M.5P5.13/2018-2019.

Informed Consent Statement: Informed consent was obtained from all subjects involved in the study. 
Data Availability Statement: The data presented in this study are available on request from the corresponding author; enidowusu115@yahoo.com; Tel.: +233-0508-917-569.

Acknowledgments: The authors wish to thank all the staff of the Departments of Medical Laboratory Sciences (SBAHS) and Medical Microbiology (UGMS) for their help. We also wish to thank all the staff of Centre for Plant Medicine Research (CPMR), Mampong-Akwapem for their assistance in various ways.

Conflicts of Interest: The authors declare no conflict of interest.

Sample Availability: Samples of plant leaves (Psidium guajava, Myrianthus arboreus, Alchornea cordifolia, Momordica charantia, and Justicia flava) are available from the authors.

\section{References}

1. Aslam, B.; Wang, W.; Arshad, M.I.; Khurshid, M.; Muzammil, S.; Rasool, M.H.; Nisar, M.A.; Alvi, R.F.; Aslam, M.A.; Qamar, M.U.; et al. Antibiotic resistance: A rundown of a global crisis. Infect. Drug Resist. 2018, 11, 1645-1658. [CrossRef] [PubMed]

2. Rossolini, G.M.; Arena, F.; Pecile, P.; Pollini, S. Update on the antibiotic resistance crisis. Curr. Opin. Pharmacol. 2014, 18, 56-60. [CrossRef]

3. Anand, U.; Jacobo-Herrera, N.; Altemimi, A.; Lakhssassi, N. A Comprehensive Review on Medicinal Plants as Antimicrobial Therapeutics: Potential Avenues of Biocompatible Drug Discovery. Metabolites 2019, 9, 258. [CrossRef]

4. Mavar-Mangar, H.; Lejoly, J.; Quetin-Leclercq, J.; Schelzer, G.H. Alchornea Cordifolia (Schumach. E Thonn.) Müll.Arg.; PROTA: Wageningen, The Netherlands, 2007.

5. Lopes, A.P.; Galuch, M.B.; Petenuci, M.E.; Oliveira, J.H.; Canesin, E.A.; Schneider, V.V.A.; Visentainer, J.V. Quantification of phenolic compounds in ripe and unripe bitter melons (Momordica charantia) and evaluation of the distribution of phenolic compounds in different parts of the fruit by UPLC-MS/MS. Chem. Pap. 2020, 74, 2613-2625. [CrossRef]

6. Nagasawa, H.; Watanabe, K.; Inatomi, H. Effects of bitter melon (Momordica charantia) or ginger rhizome (Zingiber offifinale Rosc.) on spontaneous mammary tumorigenesis in SHN mice. Am. J. Clin. Med. 2002, 30, 195-205. [CrossRef]

7. Agyare, C.; Asase, A.; Lechtenberg, M.; Niehues, M.; Deters, A. An ethnopharmacological survey and in vitro confirmation of ethnopharmacological use of medicinal plants used for wound healing in Bosomtwi-Atwima-Kwanwoma area, Ghana. J. Ethnopharmacol. 2009, 125, 393-403. [CrossRef]

8. Burkill, H.M. The Useful Plants of West Tropical Africa, 3rd ed.; Royal Botanic Gardens: Kew, UK, 2000.

9. Corrêa, G.M.; Alcantara, A.F.C. Chemical constituents and biological activities of species of Justicia-Review. Rev. Bras. Farmacogn. 2012, 22, 220-238. [CrossRef]

10. Amborabé, B.; Fleurat-Lessard, P.; Chollet, J.; Roblin, G. Antifungal effects of salicylic acid and other benzoic acid derivatives towards Eutypa lata: Structure-activity relationship. Plant Physiol. Biochem. 2002, 40, 1051-1060. [CrossRef]

11. Rajakumar, N.; Shivanna, M.B. Ethno-medicinal application of plants in the eastern region of Shimoga district, Karnataka, India. J. Ethnopharmacol. 2009, 126, 64-73. [CrossRef]

12. Ross, I.A. Psidium guajava. In Medicinal Plants of the World; Humana Press: Totowa, NJ, USA, 2003. [CrossRef]

13. Abubakar, E.M. The use of Psidium guajava Linn. in treating wound, skin and soft tissue infections. Sci. Res. Essay 2009, 4, 605-611.

14. Agyare, C.; Bempah, S.B.; Boakye, Y.D.; Ayande, P.G.; Adarkwa-Yiadom, M.; Mensah, K.B. Evaluation of Antimicrobial and Wound Healing Potential of Justicia flava and Lannea welwitschii. Evid. Based Complement. Altern. Med. 2013, 632927. [CrossRef]

15. Farzaei, M.H.; Abbasabadi, Z.; Shams-Ardekani, M.R.; Abdollahi, M.; Rahimi, R. A comprehensive review of plants and their active constituents with wound healing activity in traditional Iranian medicine. Wounds 2014, 26, 197-206.

16. Udegbunam, S.O.; Udegbunam, R.I.; Muogbo, C.C.; Anyanwu, M.U.; Nwaehujor, C.O. Wound healing and antibacterial properties of methanolic extract of Pupalia lappacea Juss in rats. BMC Complement. Altern. Med. 2014, 14, 157. [CrossRef] [PubMed]

17. Udegbunam, S.O.; Udegbunam, R.I.; Nnaji, T.O.; Anyanwu, M.U.; Kene, R.O.; Anika, S.M. Antimicrobial and antioxidant effect of methanolic Crinum jagus bulb extract in wound healing. J. Intercult. Ethnopharmacol. 2015, 4, 239-248. [CrossRef]

18. Boakye, Y.D.; Agyare, C.; Ayande, G.P.; Titiloye, N.; Asiamah, E.A.; Danquah, K.O. Assessment of Wound-Healing Properties of Medicinal Plants: The Case of Phyllanthus muellerianus. Front. Pharmacol. 2018, 9, 945. [CrossRef]

19. Sukhdev, S.H.; Suman, P.S.K.; Gennaro, L.; Dev, D.R. Extraction Technologies for Medicinal and Aromatic Plants, Chapter 1; United Nations Industrial Development Organization and the International Centre for Science and High Technology: Trieste, Italy, 2008.

20. Evans, W.C. Trease and Evans Pharmacognosy, 14th ed.; Bailiere Tindall, W.B., Ed.; Sauders Company Ltd.: London, UK, 1996; pp. 191-575.

21. Ryan, K.J.; Ray, C.G. (Eds.) Sherris Medical Microbiology, 4th ed.; McGraw Hill: New York, NY, USA, 2004.

22. Bauer, A.W.; Kirby, W.M.; Sherris, J.C.; Turck, M. Antibiotic susceptibility testing by a standardized single disk method. Am. J. Clin. Pathol. 1966, 45, 493-496. [CrossRef]

23. National Committee for Clinical Laboratory Standards. Performance Standards for Antimicrobial Susceptibility Testing. Fifteenth Informational Supplement. NCCLS Document M100-S15. 2005. Available online: http://www.clsi.org/ (accessed on 8 November 2020). 
24. Clinical and Laboratory Standards Institute (CLSI). Performance Standards for Antimicrobial Disk Susceptibility Tests, 13th ed.; CLSI Standard M02; Clinical and Laboratory Standards Institute: Wayne, PA, USA, 2018.

25. Appiah, K.S.; Oppong, C.P.; Mardani, H.K.; Omari, R.A.; Kpabitey, S.; Amoatey, C.A.; Onwona-Agyeman, S.; Oikawa, Y.; Katsura, K.; Fujii, Y. Medicinal Plants Used in the Ejisu-Juaben Municipality, Southern Ghana: An Ethnobotanical Study. Medicines 2018, 6, 1. [CrossRef]

26. Djimeli, M.N.; Fodouop, S.P.C.; Njateng, G.S.S.; Fokunang, C.; Tala, D.S.; Kengni, F.; Gatsing, D. Antibacterial activities and toxicological study of the aqueous extract from leaves of Alchornea cordifolia (Euphorbiaceae). BMC Complement. Altern. Med. 2017, 17, 349. [CrossRef]

27. Jia, S.; Shen, M.; Zhang, F.; Xie, J. Recent Advances in Momordica charantia: Functional Components and Biological Activities. Int. J. Mol. Sci. 2017, 18, 2555. [CrossRef] [PubMed]

28. Noundou, X.S.; Krause, R.W.M.; Van Vuuren, S.F.; Ndinteh, D.T.; Olivier, D.K. Antibacterial effects of Alchornea cordifolia (Schumach. and Thonn.) Müll. Arg extracts and compounds on gastrointestinal, skin, respiratory and urinary tract pathogens. J. Ethnopharmacol. 2016, 179, 76-82. [CrossRef]

29. Wang, S.; Zheng, Y.; Xiang, F.; Li, S.; Yang, G. Antifungal activity of Momordica charantia seed extracts toward the pathogenic fungus Fusarium solani L. J. Food Drug Anal. 2016, 24, 881-887. [CrossRef]

30. Chan, K.W.; Iqbal, S.; Khong, N.M.H.; Ooi, D.J.; Ismail, M. Antioxidant activity of phenolics-saponins rich fraction prepared from defatted kenaf seed meal. LWT Food Sci. Technol. 2014, 56, 181-186. [CrossRef]

31. Akbari, S.; Abdurahman, N.H.; Yunus, R.M. Optimization of saponins, phenolics, and antioxidants extracted from fenugreek seeds using microwave-assisted extraction and response surface methodology as an optimizing tool. Comptes Rendus Chim. 2019, 22, 714-727. [CrossRef]

32. Panche, A.N.; Diwan, A.D.; Chandra, S.R. Flavonoids: An overview. J. Nutr. Sci. 2016, 5, e47. [CrossRef] [PubMed]

33. De Andrade Monteiro, C.; Ribeiro Alves dos Santos, J. Phytochemicals and Their Antifungal Potential Against Pathogenic Yeasts. In Phytochemicals in Human Health [Working Title]; IntechOpen: London, UK, 2019.

34. Martins, N.; Barros, L.; Santos-Buelga, C.; Henriques, M.; Silva, S.; Ferreira, I.C.F.R. Evaluation of bioactive properties and phenolic compounds in different extracts prepared from Salvia officinalis L. Food Chem. 2015, 170, 378-385. [CrossRef] [PubMed]

35. Tekele, S.G.; Teklu, D.S.; Tullu, K.D.; Birru, S.K.; Legese, M.H. Extended-spectrum Beta-lactamase and AmpC beta-lactamases producing gram negative bacilli isolated from clinical specimens at International Clinical Laboratories, Addis Ababa, Ethiopia. PLoS ONE 2020, 15, e0241984. [CrossRef] [PubMed]

36. Yılmaz, N.; Ağuş, N.; Bayram, A.; Şamlığlu, P.; Şirin, M.C.; Derici, Y.K.; Hanc1, S.Y. Antimicrobial susceptibilities of Escherichia coli isolates as agents of community-acquired urinary tract infection (2008-2014). Turk. J. Urol. 2016, 42, 32-36. [CrossRef] [PubMed]

37. Yayan, J.; Ghebremedhin, B.; Rasche, K. Antibiotic Resistance of Pseudomonas aeruginosa in Pneumonia at a Single University Hospital Center in Germany over a 10-Year Period. PLoS ONE 2015, 10, e0139836. [CrossRef]

38. Siddiqua, M.; Alam, A.; Akter, S.; Ferdousi, R. Antibiotic resistance pattern in pseudomonas aeruginosa isolated from a private Medical College Hospital. KYAMC J. 2018, 9, 16-19. [CrossRef]

39. Goswami, N.; Goswami, A.P.; Tripathi, C.; Trivedi, H.; Patel, T. Antibiotic sensitivity profile of bacterial pathogens in postoperative wound infections at a tertiary care hospital in Gujarat, India. J. Pharmacol. Pharmacother. 2011, 2, 158. [CrossRef]

40. Tesfahunegn, Z.; Asrat, D.; Woldeamanuel, Y.; Estifanos, K. Bacteriology of surgical site and catheter related urinary tract infections among patients admitted in Mekelle Hospital, Mekelle, Tigray, Ethiopia. Ethiop. Med. J. 2009, 47, $117-127$.

41. Deyno, S.; Fekadu, S.; Astatkie, A. Resistance of Staphylococcus aureus to antimicrobial agents in Ethiopia: A meta-analysis. Antimicrob. Resist. Infect. Control 2017, 6, 85. [CrossRef] [PubMed]

42. Meseret, G.; Kassaye, A.; Yared, M. Bacteria from infected surgical wounds and their antimicrobial resistance in Hawassa University Referral Teaching Hospital, Southern Ethiopia. Afr. J. Microbiol. Res. 2014, 8, 1118-1124. [CrossRef]

43. Mulu, W.; Kibru, G.; Beyene, G.; Damtie, M. Postoperative Nosocomial Infections and Antimicrobial Resistance Pattern of Bacteria Isolates among Patients Admitted at Felege Hiwot Referral Hospital, Bahirdar, Ethiopia. Ethiop. J. Health Sci. 2012, $22,7-18$. [PubMed]

44. Raza, M.S.; Chander, A.; Ranabhat, A. Antimicrobial Susceptibility Patterns of the Bacterial Isolates in Post-Operative Wound Infections in a Tertiary Care Hospital, Kathmandu, Nepal. Open. J. Med. Microbiol. 2013, 3, 159-163.

45. Ma, X.X.; Wang, E.H.; Liu, Y.; Luo, E.J. Antibiotic susceptibility of coagulase-negative staphylococci (CoNS): Emergence of teicoplanin-non-susceptible CoNS strains with inducible resistance to vancomycin. J. Med. Microbiol. 2011, 60, 1661-1668. [CrossRef] [PubMed]

46. Sharma, D.; Misba, L.; Khan, A.U. Antibiotics versus biofilm: An emerging battleground in microbial communities. Antimicrob. Resist. Infect. Control 2017, 8, 76. [CrossRef] [PubMed]

47. Omar, A.; Wright, J.B.; Schultz, G.; Burrell, R.; Nadworny, P. Microbial Biofilms and Chronic Wounds. Microorganisms 2017, 5, 9. [CrossRef]

48. Igbeneghu, O.A.; Iwalewa, E.O.; Lamikanra, A. A study of the In Vivo activity of the leaf extract of Alchornea cordifolia against multiply antibiotic resistant $S$. aureus isolate in mice. Phytother. Res. 2007, 21, 67-71. [CrossRef]

49. Ebi, G.C. Antimicrobial activities of Alchornea cordifolia. Fitoterapia 2001, 72, 69-72. [CrossRef] 
50. Adeyemi, I.A.; Omonigbehin, A.E.; Stella, S.; Oluwatosin, O.; Jumoke, S. Antibacterial activity of extracts of Alchornea cordifolia (Schum and Thonn) Mull. Arg., Boerhavia diffusa (L.) and Bridellia micranthal (Hoscht) Baill. used in traditional medicine in Nigeria on Helicobacter pylori and four diarrhoeagenic bacterial pathogens. Afr. J. Biotechnol. 2008, 7, 3761-3764.

51. Okeke, I.N.; Ogundaini, A.O.; Ogungbamila, F.O.; Lamikanro, A. Antimicrobial spectrum of Alchornea cordifolia leaf extract. Phytother. Res. 1999, 13, 67-69. [CrossRef]

52. Ajali, U. Antibacterial activities of Alchornea cordifolia stem bark. Filoterapia 2000, 71, 436-438. [CrossRef]

53. Agyare, C.; Ansah, A.O.; Ossei, P.P.S.; Apenteng, J.A.; Boakye, Y.D. Wound Healing and Anti-Infective Properties of Myrianthus arboreus and Alchornea cordifolia. Med. Chem. 2014, 4, 533-539. [CrossRef]

54. Mwambete, K.D. The in vitro antimicrobial activity of fruit and leaf crude extracts of Momordica charantia: A Tanzania medicinal plant. Afr. Health Sci. 2009, 9, 34-39. [PubMed]

55. Abdelrahim, S.I.; Almagboul, A.Z.; Omer, M.E.A.; Elegami, A. Antimicrobial activity of Psidium guajava L. Fitoterapia 2002, 73, 713-715. [CrossRef]

56. Lins, T.H.; Santos Veríssimo, R.; Evangelista Santos, R.F.; Assis Bastos, M.; Correia Bernardo, R.C.; Alvino, V.; Albuquerque Sarmento, P.D.; Araújo Júnior, J.X. Evaluation of antimicrobial activity of Psidium guajava species. BMC Proc. 2014, 8 (Suppl. S4), 79. [CrossRef] 